Revista Eletrônica de Direito Processual - REDP.

Rio de Janeiro. Ano 13. Volume 20. Número 1. Janeiro a Abril de 2019

Periódico Quadrimestral da Pós-Graduação Stricto Sensu em Direito Processual da UERJ

Patrono: José Carlos Barbosa Moreira (in mem.). ISSN 1982-7636. pp. 442-476

www.redp.uerj.br

\title{
DA IMPARCIALIDADE DO JULGADOR À LUZ DO NOVO CÓDIGO DE PROCESSO CIVIL ${ }^{1}$
}

\section{THE JUDGE'S IMPARTIALITY UNDER THE PERPECTIVE OF THE 2015 CODE OF CIVIL PROCEDURE}

Reis Friede

Desembargador Federal, Presidente do Tribunal Regional Federal da $2^{\text {a }}$ Região (biênio 2019/21), Mestre e Doutor em Direito e Professor Adjunto da Universidade Federal do Estado do Rio de Janeiro (UNIRIO). E-mail: assessoriareisfriede@hotmail.com

RESUMO: O presente artigo analisa a questão inerente à imparcialidade do julgador, debruçando-se, inicialmente, sobre sua disciplina normativa pretérita, examinando os aspectos relativos ao impedimento e à suspeição. Posteriormente, enfoca as principais alterações promovidas pelo Código de Processo Civil de 2015 nestes institutos, destacando os aspectos doutrinários e jurisprudenciais sobre o tema.

PALAVRAS-CHAVE: Imparcialidade. Suspeição. Impedimento. Código de Processo Civil de 2015.

ABSTRACT: This article examines the issue of impartiality of the judge initially focusing on its pre-normative discipline, examining aspects related to impediment and surmise. Subsequently it focuses on the main changes promoted by the 2015 Code of Civil Procedure in these institutes highlighting the doctrinal and jurisprudential aspects on the subject.

KEYWORDS: Impartiality. Surmise. Impediment. 2015 Code of Civil Procedure.

\footnotetext{
${ }^{1}$ Artigo recebido em 11/12/2017 e aprovado em 30/04/2019.
} 


\section{INTRODUÇÃO}

O caráter de imparcialidade ${ }^{2}$ do julgador (pessoa física do juiz), assim como a de seus auxiliares (diretor de secretaria, escrivão, oficial de justiça, depositário, contador etc.), desponta como condição sine qua non para o legítimo exercício da atividade jurisdicional, considerando que o Estado-juiz coloca-se entre as partes em litígio e, sobretudo, acima delas, objetivando a solução final do conflito de interesses originário, sem, em nenhum momento, propender para qualquer das partes -, visando em última instância, não só à realização do direito objetivo material ${ }^{3}$, mas fundamentalmente a preservação da ordem jurídica (e, por extensão, a necessária credibilidade) e, por conseqüência, a imposição da segurança das relações sociopolítico-econômicas, como bem assim, a própria paz social. Em outras palavras, “(...) a imparcialidade do julgador é importante para que este, mantendo-se imparcial no trato da lide, assegurar a credibilidade da ordem judicial"4.

O atributo da imparcialidade, portanto, é inseparável do órgão da jurisdição (do juízo que engloba não só o juiz (seu titular) mas todos os demais serventuários e auxiliares), como verdadeiro pressuposto de validade processual. É exatamente neste sentido que a doutrina costuma afirmar que o órgão jurisdicional deve ser subjetivamente capaz.

A primeira e mais importante qualidade de um juiz é a imparcialidade. Investido da alta missão de decidir acerca dos mais relevantes interesses das partes, munido de amplos poderes para esse fim, é indispensável que o juiz realmente julgue sem ser influenciado por quaisquer fatores que não o direito dos litigantes.

2 Qualidade de imparcial (de in + parcial), adj.: "que julga desapaixonadamente; reto, justo" (FERREIRA, Aurélio Buarque de Holanda. Novo Dicionário da Língua Portuguesa, 2a ed., Ed. Nova Fronteira, 1986. p. 920).

3 GRINOVER, Ada Pellegrini. Teoria Geral do Processo, 9ª ed., Malheiros, Ed., SP, 1993, p. 115.

4 LIEBMANN apud SILVA, Ovídio B. da. Estudos Sobre o Processo Civil Brasileiro, Saraiva, SP, 1947. 
Revista Eletrônica de Direito Processual - REDP.

Rio de Janeiro. Ano 13. Volume 20. Número 1. Janeiro a Abril de 2019

Periódico Quadrimestral da Pós-Graduação Stricto Sensu em Direito Processual da UERJ

Patrono: José Carlos Barbosa Moreira (in mem.). ISSN 1982-7636. pp. 442-476

www.redp.uerj.br

O despreparo cultural ou a morosidade do juiz pode preocupar o litigante.

Mas o fator que é realmente capaz de intranqüilizá-lo, de fazê-lo descrer na justiça humana, é a falta de confiança na isenção do juiz. ${ }^{5}$

\section{CAPACIDADE SUBJETIVA DO JULGADOR E LEGITIMAÇÃO DA ATUAÇÃO DO ESTADO-JUIZ}

A ausência de capacidade subjetiva do juiz (que se origina da suspeita de sua eventual parcialidade) afeta profundamente a relação processual, pondo dúvidas na própria legitimidade do escopo de atuação do Estado-juiz (por meio da atividade substitutiva de cunho jurisdicional), diminuindo a credibilidade social na parcela estatal exercente da função julgadora (Poder Judiciário) e, acima de tudo, permitindo a possibilidade de inviabilização do objetivo último do Estado, que é exatamente a de moderador de conflitos em nome da estabilidade social e política de toda a coletividade. “A esperança nos juízes é a última esperança". 6

Somente o equilíbrio, a serenidade, a busca, no senso exato, da interpretação da lei, a virtusa que se referiam os romanos, são capazes de conduzir o ser humano (a pessoa física do julgador) à exata aplicação do direito, traduzindo a necessária credibilidade que deve gozar o Poder Judiciário.

O Poder Judiciário é o desaguadouro natural de todos os conflitos, é o último refúgio dos injustiçados, o anteparo derradeiro de que pode dispor o cidadão para ter assegurado os seus direitos.

O Poder Judiciário mais do que qualquer outra instância estatal, há de ser merecedora de plena credibilidade (...). ${ }^{7}$

Um Judiciário digno é condição primeira da democracia, não podendo haver, sem ele, tranqüilidade e segurança para ninguém. ${ }^{8}$

\footnotetext{
${ }_{5}^{5}$ BARBI, Celso Agrícola. Comentários ao Código de Processo Civil, vol. I, $5^{\mathrm{a}}$ ed., Ed. Forense, $1983 .$, p. 546-547.

${ }^{6}$ BARBOSA, Rui. Obras Completas de Rui Barbosa. Publicado pelo Ministério de Educação e Saúde, 1942 , p. 130.

${ }^{7}$ MACHADO, Hugo de Brito. Ser e Parecer, Rev. AJUFE, dez./91, p. 54.

${ }^{8}$ DELGADO, José Luiz. A Democracia e o Judiciário, Diário de Pernambuco, 18/09/91, p. A-11.
} 
Revista Eletrônica de Direito Processual - REDP.

Rio de Janeiro. Ano 13. Volume 20. Número 1. Janeiro a Abril de 2019

Periódico Quadrimestral da Pós-Graduação Stricto Sensu em Direito Processual da UERJ

Patrono: José Carlos Barbosa Moreira (in mem.). ISSN 1982-7636. pp. 442-476

www.redp.uerj.br

O povo brasileiro clama, a todo instante, pela justiça sem imaginar quão complexa pode a mesma vir a ser em sua realização efetiva. Neste diapasão, resta oportuno reafirmar, mais uma vez (e em tom sublime), que a justiça só pode ser realizada, em sua (absoluta) plenitude, à luz da plena imparcialidade dos julgamentos e necessariamente submetida à imposição imperial da lei e da ordem jurídica que, em última instância, representam a verdadeira razão do direito que trilha (obrigatoriamente) através de um imprescindível distanciamento da paixão e de outras emoções humanas, como, por exemplo, as manifestações típicas das partes envolvidas na contenda.

Nada é mais inimigo da verdadeira justiça do que a paixão. E nada a atropela mais do que a pressa. Os julgamentos apaixonados não são julgamentos, são libelos, são atos unilaterais eivados de nulidade. Essa é a razão maior porque os parentes e os amigos íntimos não podem julgar (são impedidos), e nem mesmo testemunhar. A visão do homem cheio de ódio (e mesmo de amor) é sempre uma visão vesga, unilateral e distorcida. $^{9}$

É exatamente por esta razão, - assegurar a absoluta imparcialidade do juiz e dos julgamentos por ele presididos -, que a Constituição Federal estipula ao magistrado garantias $^{10}$, ao mesmo tempo em que lhe prescrevem vedações ${ }^{11}$ e proíbem juízos e tribunais de exceção ${ }^{12}$.

(...) pode-se afirmar, sem receio de erro, que as garantias de vitaliciedade, de inamovibilidade e de irredutibilidade de vencimentos, elevadas à culminância constitucional, e destinadas a assegurar a indendência do juiz, têm por finalidade última resguardar a sua imparcialidade.

Ainda que o juiz tenha todas as condições para a correta atuação nas causas que, em princípio, podem ir ao seu exame, há, porém, algumas em que a sua atuação pessoal, em relação às pessoas que participam do

\footnotetext{
${ }^{9}$ MEIRA, Sílvio. Clamor pela Justiça, Jornal do Comércio, 4/9/92.

10 BRASIL. Constituição (1988). Constituição da República Federativa do Brasil. Brasília, DF: Senado Federal: Centro Gráfico, 1988. 292 p., art. 95.

${ }^{11}$ Ibid

${ }^{12}$ BRASIL, op. cit., art. $5^{\circ}$, XXXVII.
} 
Revista Eletrônica de Direito Processual - REDP.

Rio de Janeiro. Ano 13. Volume 20. Número 1. Janeiro a Abril de 2019

Periódico Quadrimestral da Pós-Graduação Stricto Sensu em Direito Processual da UERJ

Patrono: José Carlos Barbosa Moreira (in mem.). ISSN 1982-7636. pp. 442-476

www.redp.uerj.br

processo, ou ao interesse em litígio, pode influir no seu espírito, de modo

a impedir um correto julgamento da demanda.

Por esse motivo, para dar tranqüilidade aos litigantes e confiança na retidão dos julgamentos, a lei manda que o juiz se afaste de determinadas causas, e permite que a parte impugne sua presença, quando ele não se afastou espontaneamente.

As razões que justificam a exclusão do juiz são de ordem subjetiva, referem-se à sua pessoa, e não ao juízo. Quando a exclusão é do juízo o assunto pertence à área da competência. Assim, quando se verifica a falta de competência do juízo, os autos vão para outro, que for competente por lei. E, se a exclusão for por motivos da pessoa do juiz, os autos permanecem no mesmo juízo, mas para serem processados e julgados por outra pessoa, que é o juiz substituto daquele que foi afastado da causa. ${ }^{13}$

Aos tribunais e juízos de exceção se contrapõe o princípio do juiz natural, que consagra três corolários fundamentais; a saber:

a) a imposição da função de julgar exclusivamente aos órgãos investidos da jurisdição (afastando a possibilidade de o órgão legislativo julgar, impondo sanções penais sem o devido e prévio processo, consoante o antigo direito inglês);

b) vedação aos juízes e tribunais ad hoc ou de exceção. O juízo ou tribunal é sempre preexistente ao fato civil ou penal a ser julgado;

c) impossibilidade de subtração da causa ao juiz constitucionalmente competente, segundo a garantia constitucional reintroduzida pela atual Carta Magna na previsão do art. $5^{\circ}$, LIII, da CF/88 ${ }^{14}$.

A imparcialidade do julgador (e, por extensão, do órgão judicante) representa a maior garantia de justiça para as partes, diante do próprio escopo de atuação do Estadojuiz, por intermédio do Poder Judiciário.

A imparcialidade do juiz é uma garantia de justiça para as partes. Por isso, têm elas o direito de exigir um juiz imparcial e o Estado, que reservou para o si o exercício da função jurisdicional, tem o

\footnotetext{
${ }^{13}$ BARBI, Celso Agrícola, op. cit., p. 547.

${ }^{14}$ BRASIL, op. cit., art. $5^{\circ}$, LIII.
} 
Revista Eletrônica de Direito Processual - REDP.

Rio de Janeiro. Ano 13. Volume 20. Número 1. Janeiro a Abril de 2019

Periódico Quadrimestral da Pós-Graduação Stricto Sensu em Direito Processual da UERJ

Patrono: José Carlos Barbosa Moreira (in mem.). ISSN 1982-7636. pp. 442-476

www.redp.uerj.br

correspondente dever de agir com imparcialidade na solução das causas que lhe são submetidas. ${ }^{15}$

\section{GARANTIA UNIVERSAL DA AMPLA IMPARCIALIDADE DOS JULGAMENTOS}

A Declaração Universal dos Direitos do Homem, contida na proclamação feita pela Assembléia-Geral das Nações Unidas (ONU) reunida em Paris, em 10 de dezembro 1948, também proclama, em termos internacionais, a garantia da ampla imparcialidade dos julgamentos dos órgãos jurisdicionais competentes, de maneira geral, - e com escopo de atuação transcendente às fronteiras nacionais -, estabelecendo, expressamente, que:

Toda pessoa tem direito, em condições de plena igualdade de ser ouvida publicamente e com justiça por um tribunal independente e imparcial para a determinação de seus direitos e obrigações ou para o exame de qualquer acusação contra ela em matéria penal. ${ }^{16}$

Essa medida representa a real (e universal) dimensão da importância da imparcialidade (e, conseqüente, do necessário distanciamento do órgão responsável e do próprio julgador em relação às partes envolvidas e também à causa) para a afirmação e o reconhecimento universal da justiça (como instituição e valor) e do processo (como instrumento não apenas técnico, mas, sobretudo, ético para a solução dos conflitos).

Como só a jurisdição, subtraída de influências estranhas, pode configurar uma justiça que dê a cada um o que é seu e, somente através da garantia de um juiz imparcial, o processo pode representar um instrumento não apenas técnico, mas também ético para a solução dos conflitos interindividuais com justiça, o moderno Direito Internacional não poderia ficar alheio ao problema das garantias fundamentais do homem, nem

\footnotetext{
${ }^{15}$ CINTRA, Antonio Cunha de A.; GRINOVER, Ada Pellegrini; DINAMARCO, Cândido R. Teoria Geral do Processo, $9^{a}$ ed., Malheiros Ed., SP, 1993, p. 51.

${ }^{16}$ DECLARAÇÃO Universal Dos Direitos Humanos. Assembleia Geral das Nações

Unidas em Paris. 10 dez. 1948, art. 10. Disponível em: <https://www.ohchr.org/EN/UDHR/Pages/Language.aspx?LangID=por>.

Acesso: 05 fev. 2019.
} 
Revista Eletrônica de Direito Processual - REDP.

Rio de Janeiro. Ano 13. Volume 20. Número 1. Janeiro a Abril de 2019

Periódico Quadrimestral da Pós-Graduação Stricto Sensu em Direito Processual da UERJ

Patrono: José Carlos Barbosa Moreira (in mem.). ISSN 1982-7636. pp. 442-476

www.redp.uerj.br

relegar a eficácia do sistema de proteção dos direitos individuais à

estrutura constitucional de cada país. Independentemente do

reconhecimento de cada Estado, o Direito Internacional Público coloca

sob sua garantia os direitos primordiais do homem, inerentes à

personalidade humana; entre eles, o direito ao juiz imparcial. ${ }^{17}$

\section{IMPARCIALIDADE ABSOLUTA OU IDEAL}

Ainda assim, resta oportuno destacar, em necessária adição (aclaratória), que não existe, no contexto da atuação prática da justiça, uma genuína (e ideal) imparcialidade absoluta, posto que a expressão epigrafada é utilizada, na verdade, para propiciar a necessária ênfase que se deseja conferir ao caráter fundamental da imparcialidade do julgador.

Os magistrados, embora com atividades restringidas pela lei, são seres pensantes e culturalmente instruídos que, necessariamente, possuem opiniões pessoais sobre assuntos políticos e uma correspondente ideologia particular. Sua imparcialidade, portanto, jamais poderá ser considerada em termos absolutos (no sentindo literal do vocábulo), muito embora deva ser, no mínimo, relativa, ou seja, aferida restritivamente às partes, ao processo e à causa sub judice.

Nessa toada, vale concluir que o bom julgador é sempre aquele que consegue deixar sua formação política, suas opiniões e conviç̧ões pessoais em segundo plano e colocar, acima destas e por meio de um necessário distanciamento em relação às partes e à causa, a preservação da ordem jurídica e, por via de consequiência, a imperatividade do Direito Positivo vigente ${ }^{18}$.

\section{IMPARCIALIDADE DO JULGADOR E DO ÓRGÃO JURISDICIONAL}

Sobre a imparcialidade do julgador e a do órgão jurisdicional, Giusepe Chiovenda leciona que "há uma incompatibilidade psicológica ainda maior entre a tarefa do administrador e a jurisdicional do magistrado, porque o administrador pode ser

\footnotetext{
${ }^{17}$ GRINOVER, Ada Pellegrini, op. cit., p. 51.
} 
Revista Eletrônica de Direito Processual - REDP.

Rio de Janeiro. Ano 13. Volume 20. Número 1. Janeiro a Abril de 2019

Periódico Quadrimestral da Pós-Graduação Stricto Sensu em Direito Processual da UERJ

Patrono: José Carlos Barbosa Moreira (in mem.). ISSN 1982-7636. pp. 442-476

www.redp.uerj.br

dominado pelo interesse do Estado. (...) A própria administração julga: mas o faz sobre a própria atividade. Ao contrário, a jurisdição julga a atividade alheia e duma vontade de lei concretamente a outrem."19

Vale salientar que a capacidade subjetiva do juiz, que constitui a sua imparcialidade e isenção frente à causa, também implica a "liberdade do órgão valorar aquilo que o Estado considera, em certo momento, o direito vigente e a segurança da parte em relação ao provimento que soluciona a lide, que espera seja sempre previsíve.l"20

A própria impossibilidade das partes litigarem diretamente nos autos, dentre outras razões, também deriva do fato de estarem envolvidas emocionalmente com a causa, razão pela qual devem (ainda que existam exceções) estar sempre representados por advogados que, - muito embora sejam reconhecidamente defensores incontestes dos interesses dos seus clientes -, não se encontram envolvidos diretamente na causa e, portanto, não participam do chamado "mar de emoções" que impede às partes litigantes a visão equilibrada e serena para a solução do conflito. Em outras palavras, os advogados são parciais, mas atuam de forma impessoal.

Vale esclarecer, em necessária adição, que o advogado, diferente do magistrado, é figura que defende interesse da parte (individual ou coletiva), mas sempre de existência concreta, e, por via de conseqüência (apesar de nutrir um determinado distanciamento da paixão própria de seu cliente), não deixa de possuir a parcialidade que é, de todas as formas, vedada ao juiz.

Por outro prisma, o membro do Ministério Público, de maneira diversa, ostenta várias e distintas posições no processo que vão desde a titularidade exclusiva da ação penal pública, passando pela de fiscal da lei e de sua correta aplicação, até a de defensor da sociedade. Nesta última, mais do que em qualquer das outras, resta claro que o membro do parquet é figura que não possui a característica da completa imparcialidade (exclusiva do magistrado), porquanto, ao se constituir em defensor sublime dos interesses da sociedade, patrocina interesses de uma parte, ainda que coletiva e abstrata, caracterizando uma imparcialidade relativa. Portanto, é cediço concluir que apenas os Juízes ostentam uma

\footnotetext{
${ }^{19}$ CHIOVENDA, Giusepe. Instituições de Direito Processual Civil, vol. II, Ed. Bookseller. Campinas, 1998, p. 23.

${ }^{20}$ ASSIS, Araken de. Manual de Processo de Execução, Sérgio Fabris Ed., RS, 1987.
} 
Revista Eletrônica de Direito Processual - REDP.

Rio de Janeiro. Ano 13. Volume 20. Número 1. Janeiro a Abril de 2019

Periódico Quadrimestral da Pós-Graduação Stricto Sensu em Direito Processual da UERJ

Patrono: José Carlos Barbosa Moreira (in mem.). ISSN 1982-7636. pp. 442-476

www.redp.uerj.br

imparcialidade absoluta (ainda que considerada em um contexto real e não idealizado), tendo em vista o seu exclusivo compromisso com o direito e com a correta interpretação e aplicação do mesmo.

Nada obstante e ainda que reconhecida a capacidade subjetiva do julgador como o seu mais considerável atributo (na condição de lastro último do mais importante princípio que instrui o processo e o direito processual, de modo geral), este, a toda evidência, também se constitui em um elemento subjetivo complexo (no mínimo) de difícil aferição.

\section{CAPACIDADE SUBJETIVA DO JULGADOR, GARANTIAS CONSTITUCIONAIS DA MAGISTRATURA E PREVISÃO LEGISLATIVA DOS VÍCIOS DE PARCIALIDADE}

Por esta razão, a necessidade constitucional de conferir à magistratura um autêntico elenco de garantias lato sensu que visam, acima de tudo, a prover a imprescindível independência do juiz em relação aos demais entes estatais (e a todo tipo de pressão de caráter político-governamental), procurando evitar, em última análise, a denominada "justiça de gabinete".

Todavia, independentemente da existência de todo um complexo sistema de acautelamento constitucionalmente assegurado em nosso ordenamento jurídico maior, existe uma série de fatores (atinentes a cada juiz como pessoa física, política e ideologicamente consciente) que não pode ser prevista (e disciplinada) de forma objetiva e completa pela lei, no seu sentido mais amplo.

A legislação processual em vigor, mesmo sem a possibilidade (efetiva) de antecipar de modo absoluto todas as hipóteses nas quais for possível ocorrer o vício da imparcialidade do julgador, procura alcançar, de todas as maneiras, este desiderato, elencando, por seu turno, de maneira clara, alguns dos elementos básicos que frustram a necessária isenção do magistrado.

Estes elementos (ou fatores) dizem respeito precipuamente à relação que pode ostentar o julgador, em face das partes (autor e réu na qualidade de "partes principais", de maneira geral; e o Ministério Público e os eventuais terceiros intervenientes, na qualidade 
Revista Eletrônica de Direito Processual - REDP.

Rio de Janeiro. Ano 13. Volume 20. Número 1. Janeiro a Abril de 2019

Periódico Quadrimestral da Pós-Graduação Stricto Sensu em Direito Processual da UERJ

Patrono: José Carlos Barbosa Moreira (in mem.). ISSN 1982-7636. pp. 442-476

www.redp.uerj.br

de "partes secundárias", de forma adiáfora); do objeto da causa, ou mesmo, dos outros órgãos jurisdicionais. ${ }^{21}$

A este propósito, consoante ensinamentos de Chiovenda ${ }^{22}$, as condições de capacidade subjetiva do julgador poderiam, também, ser classificadas como absolutas (ainda que em um contexto jurídico real e não idealizado) e relativas, e todas, em qualquer hipótese, seriam sempre extensíveis, por analogia (interpretativa ou integrativa da norma jurídica disciplinadora), ou mesmo por expressa disposição legal, aos escrivães (e assemelhados) e aos peritos (de todos os tipos), com conseqüências processuais e forma de argüição explicitamente definidas, a partir da própria natureza do vício em questão.

Os fatores que ensejam a frustração da imparcialidade do julgador estão, de modo geral, enumerados na lei - notadamente no Código de Processo Civil (arts. 144 e 145) $)^{23}$, no Código de Processo Penal (arts. 112, 252 a 258, 274, 280 e 281) ${ }^{24}$, na Consolidação das Leis do Trabalho - CLT (art. 801) ${ }^{25}$ e nas diversas leis de organização judiciária -, sob a rubrica genérica de suspeição, impedimento e incompatibilidade.

\section{VÍCIOS DE PARCIALIDADE DO JULGADOR E COMPETÊNCIA DO JUÍZO}

Muito embora os vícios que maculam a parcialidade do julgador não se traduzam exclusivamente pela incompetência do mesmo (na medida em que tal instituto processual é previsto especificamente para a situação relativa que pode ostentar o juiz em relação a outros órgãos jurisdicionais), é oportuno assinalar que alguns autores têm traduzindo os pressupostos de validade do processo, referente à existência de órgão investido da função jurisdicional competente, não-suspeito, não-impedido (e, por extensão, não incompatível), pela rubrica genérica de "órgão jurisdicional competente".

\footnotetext{
${ }^{21}$ ASSIS, Araken de, op. cit.

${ }^{22}$ CHIOVENDA, Giusepe, op. cit.

23 BRASIL. Lei $\mathrm{n}^{\circ}$ 13.105, de 16 de Março de 2015. Código de Processo Civil. Disponível em: <http://www.planalto.gov.br/ccivil_03/_Ato2015-2018/2015/Lei/L13105.htm\#art1046>. Acesso: 04 fev. 2019.

${ }^{24}$ BRASIL. Decreto-Lei no 3.689, de 3 de Outubro de 1941. Código de Processo Penal. - Brasília: Senado Federal, Coordenação de Edições Técnicas, 2017. 187 p. Disponível em: <http://www2.senado.leg.br/bdsf/bitstream/handle/id/529749/codigo_de_processo_penal_1ed.pdf>. Acesso: 04 fev. 2019.

${ }^{25}$ BRASIL. Consolidação das leis do trabalho - CLT e normas correlatas. - Brasília:

Senado Federal, Coordenação de Edições Técnicas, 2017.189 p. Disponível em: <http://www2.senado.leg.br/bdsf/bitstream/handle/id/535468/clt_e_normas_correlatas_1ed.pdf>. Acesso: 04 fev. 2019.
} 
Revista Eletrônica de Direito Processual - REDP.

Rio de Janeiro. Ano 13. Volume 20. Número 1. Janeiro a Abril de 2019

Periódico Quadrimestral da Pós-Graduação Stricto Sensu em Direito Processual da UERJ

Patrono: José Carlos Barbosa Moreira (in mem.). ISSN 1982-7636. pp. 442-476

www.redp.uerj.br

Tal designação, - ainda que não possa ser rotulada como plenamente errônea,

considerando o variado espectro de sentidos técnico-jurídicos possíveis para a expressão em questão -, é, no mínimo, imprecisa à luz do rigor científico da ciência hermenêutica jurídica, em virtude da possibilidade de se conduzir a eventuais equívocos da correta interpretação dos fenômenos processuais que lhe são presentes.

A competência do juiz delimitada pela lei, consoante ensinamentos de Carnelutti $^{26}$, depende fundamentalmente da ausência de determinadas relações objetivas com as partes, com outros juízes e do não-julgamento anterior que torne "prejudicado" o atual.

Porém, uma variada gama de situações relativas às partes, sob o prisma subjetivo, assim como situações da relação do julgador em face do objeto da causa, não se encontram propriamente na esfera restrita da competência do juiz (ou do órgão jurisdicional), transcendendo esta limitada condicionante para, - dentro do contexto do gênero "pressuposto de validade do processo assente na existência de órgão jurisdicional legitimamente investido da função em epígrafe" -, caracterizar, pelo menos, outras duas espécies distintas: a incompatibilidade e o impedimento "lato sensu" (incluindo a suspeição).

\section{TRÍADE DOS VÍCIOS DE CAPACIDADE SUBJETIVA DO JULGADOR: INCOMPATIBILIDADE, IMPEDIMENTO E SUSPEIÇÃO}

A doutrina contemporânea, no entanto, acabou por sacramentar, mais tarde, a distinção vocabular entre o impedimento e a suspeição, consagrando a denominada tríade dos vícios de capacidade subjetiva do julgador: incompatibilidade, impedimento e suspeição.

Desta feita, muito embora, por vezes de forma equivocada, vislumbra-se a "suspeição" quando, na verdade, há "impedimento"; ou utiliza-se o termo "incompatibilidade" para designar, invariavelmente, qualquer destas distintas hipóteses, a lei atual refere-se (de modo expresso e taxativo) às três diferentes condições de vícios subjetivos (além da condição de vício de ausência objetiva de poder jurisdicional, caracterizada pela denominada presença ou ausência de competência), que afastam o

\footnotetext{
${ }^{26}$ FILHO, Fernando da Costa Tourinho. Processo Penal, vol. II, ed. Saraiva, 12a edição, 2009, p. 400.
} 
Revista Eletrônica de Direito Processual - REDP.

Rio de Janeiro. Ano 13. Volume 20. Número 1. Janeiro a Abril de 2019

Periódico Quadrimestral da Pós-Graduação Stricto Sensu em Direito Processual da UERJ

Patrono: José Carlos Barbosa Moreira (in mem.). ISSN 1982-7636. pp. 442-476

www.redp.uerj.br

indispensável pressuposto de validade processual, ou seja, a existência do órgão legitimamente investido da função jurisdicional.

Esquematicamente (e de forma bastante simplificada), pode-se efetuar a seguinte distinção entre os três institutos: o vínculo do juiz com qualquer das partes caracterizaria a suspeição; a relação de interesses do magistrado com o objeto do processo evidenciaria o impedimento; e as graves razões de conveniência não incluídas entre os casos de suspeição e impedimento assinalariam (pelo critério excludente) a incompatibilidade.

Diagrama 1: Vícios de Capacidade Subjetiva do Julgador

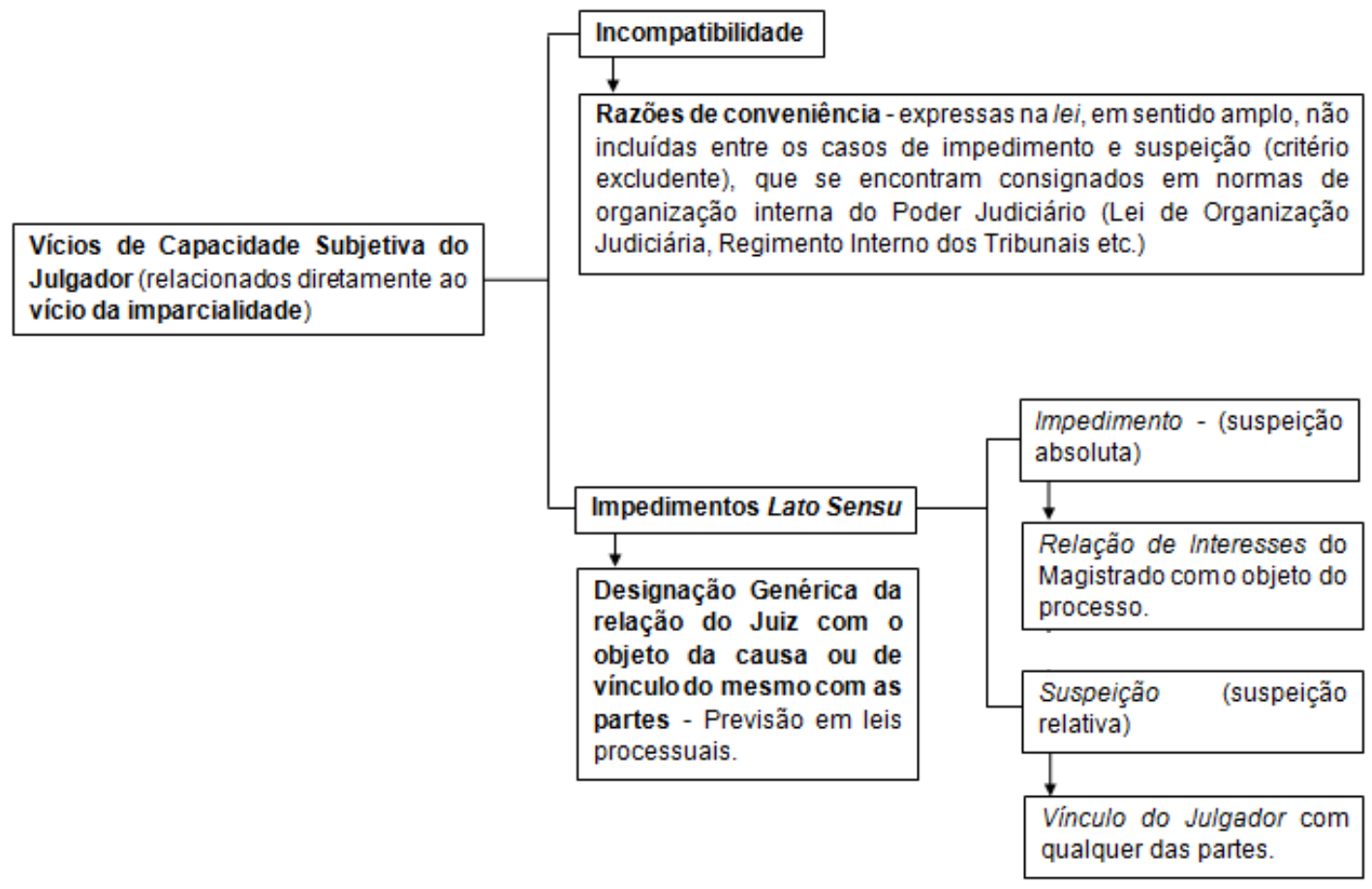

Fonte: próprio autor

A doutrina também tem procurado estabelecer diferenças mais tangíveis entre os três vícios subjetivos do julgador, notadamente entre a incompatibilidade e o impedimento. Sob o arcabouço puramente formal, a tentativa de distinguir mais profunda e objetivamente os dois institutos fundamentou-se no fato de que o primeiro possuiria previsão normativa registrada em regras de organização interna do Poder Judiciário (norma jurídica de produção legislativa em sentido atípico), enquanto o segundo teria 
Revista Eletrônica de Direito Processual - REDP.

Rio de Janeiro. Ano 13. Volume 20. Número 1. Janeiro a Abril de 2019

Periódico Quadrimestral da Pós-Graduação Stricto Sensu em Direito Processual da UERJ

Patrono: José Carlos Barbosa Moreira (in mem.). ISSN 1982-7636. pp. 442-476

www.redp.uerj.br

assegurado seu registro em leis processuais (Código de Processo Civil e Penal). Tal distinção, embora possa ser considerada em termos indicativos, esbarra, todavia, na disciplina dos artigos 252 e 253 do $\mathrm{CPP}^{27}$ que registram e, por vezes, confundem as hipóteses de incompatibilidade e impedimento.

Por sua vez, vale ressaltar que os vícios de capacidade subjetiva do julgador, notadamente os associados aos denominados impedimentos "lato sensu", serão sempre aferidos de acordo com a subsunção do caso concreto, à norma disciplinadora das situações abstratas que presumem a existência de parcialidade do julgamento.

\section{A EVOLUÇÃO HISTÓRICO-LEGISLATIVA dOS VÍCIOS DE CAPACIDADE SUBJETIVA DO JULGADOR NA LEGISLAÇÃO PROCESSUAL CIVIL BRASILEIRA}

O Código de Processo Civil de $1939^{28}$ elencava - sob a rubrica genérica de suspeição (e não de impedimento) - todas as hipóteses de ausência da necessária isenção do magistrado em seu art. 185, verbis:

Código de Processo Civil de 1939:

Art. 185 - Considera-se fundada a suspeita de parcialidade do juiz quando:

I - parentes consagüíneo de alguma das partes, ou seus procuradores, até terceiro grau;

II - amigo íntimo ou inimigo capital de alguma das partes;

III - particularmente interessado na decisão da causa;

IV - ele ou qualquer de seus parentes consagüíneos ou afins, até o terceiro grau, tiver interesse direto em transação em que haja intervindo, ou esteja para intervir alguma das partes. ${ }^{29}$

Diferente, pois, da legislação processual civil subsequente (de 1973), bem como da que está atualmente em vigor (sancionada em 2015), o diploma processual de

\footnotetext{
${ }^{27}$ BRASIL, op. cit.

${ }^{28}$ BRASIL. Decreto-Lei ${ }^{\circ}$ 1.608, de 18 de Setembro de 1939. Código de Processo Civil. Disponível em: <http://www.planalto.gov.br/ccivil_03/decreto-lei/1937-1946/Del1608.htm>. Acesso: 04 fev. 2019.

${ }^{29}$ Ibid.
} 
Revista Eletrônica de Direito Processual - REDP.

Rio de Janeiro. Ano 13. Volume 20. Número 1. Janeiro a Abril de 2019

Periódico Quadrimestral da Pós-Graduação Stricto Sensu em Direito Processual da UERJ

Patrono: José Carlos Barbosa Moreira (in mem.). ISSN 1982-7636. pp. 442-476

www.redp.uerj.br

1939 não estabelecia diferenças entre os dois vícios básicos, o que normalmente se espera

da prática normativa que provê mecanismos diversos para assegurar uma efetiva garantia complementar, em face do princípio da imparcialidade do julgador, o que impôs, por conseqüência, a imperiosa necessidade de que um novo Código de Processo Civil ${ }^{30}$ (em 1973) firmasse importantes distinções entre os dois institutos fundamentais, atinentes ao vício de capacidade subjetiva do juiz: o impedimento e a suspeição.

Código de Processo Civil de 1973:

Art. 134 - É defeso ao juiz exercer as suas funções no processo contencioso ou voluntário:

I - de que for parte;

II - em que interveio como mandatário da parte, oficiou como perito, funcionou como órgão do Ministério Público, ou prestou depoimento como testemunha;

III - que conheceu em primeiro grau de jurisdição, tendo-lhe proferido sentença ou decisão;

IV - quando nele estiver postulando, com advogado da parte, o seu cônjuge ou qualquer parente seu, consagüíneo ou afim em linha reta; ou em linha colateral até o segundo grau;

V - quando cônjuge, parente, consangüíneo ou afim, de alguma das partes, em linha reta ou, na colateral, até o terceiro grau;

VI - quando for órgão de direção ou na de administração de pessoa jurídica, parte na causa.

Parágrafo único - No caso do $\mathrm{n}^{\circ} \mathrm{IV}$, o impedimento só se verifica quando o advogado já estava exercendo o patrocínio da causa; é, porém, vedado ao advogado pleitear no processo, a fim de criar o impedimento do juiz.

Art. 135 - Reputa-se fundada a suspeição de parcialidade do juiz, quando: I - amigo íntimo ou inimigo capital de qualquer das partes;

II - alguma das partes dor credora ou devedora do juiz, de seu cônjuge ou de parentes destes, em linha reta ou na colateral até o terceiro grau;

III - herdeiro presuntivo, donatário ou empregador de alguma das partes;

${ }^{30}$ BRASIL. Lei $\mathrm{n}^{\circ}$ 5.869, de 11 de Janeiro de 1973. Institui o Código de Processo Civil. Disponível em: <http://www.planalto.gov.br/ccivil_03/LEIS/L5869impressao.htm>. Acesso: 04 fev. 2019. 
Revista Eletrônica de Direito Processual - REDP.

Rio de Janeiro. Ano 13. Volume 20. Número 1. Janeiro a Abril de 2019

Periódico Quadrimestral da Pós-Graduação Stricto Sensu em Direito Processual da UERJ

Patrono: José Carlos Barbosa Moreira (in mem.). ISSN 1982-7636. pp. 442-476

www.redp.uerj.br

IV - receber dádivas antes ou depois de iniciado o processo; aconselhar

alguma das partes acerca do objeto da causa, ou subministrar meios para

atender às despesas do litígio;

$\mathrm{V}$ - interessado no julgamento da causa em favor de uma das partes.

Parágrafo único - Poderá ainda o juiz declarar-se suspeito por motivo íntimo.

Art. 136 - Quando dois ou mais juízes forem parentes, consangüíneos ou afins, em linha reta e no segundo grau na linha colateral, o primeiro que conhecer da causa no tribunal impede que o outro participe do julgamento; caso em que o segundo se escusará, remetendo o processo ao seu substituto legal. ${ }^{31}$

O mandamento legal, em certo aspecto, foi reproduzido pela atual normatividade processual inaugurada em 2015, verbis:

Código de Processo Civil de 2015:

Art. 144. Há impedimento do juiz, sendo-lhe vedado exercer suas funções no processo:

I - em que interveio como mandatário da parte, oficiou como perito, funcionou como membro do Ministério Público ou prestou depoimento como testemunha;

II - de que conheceu em outro grau de jurisdição, tendo proferido decisão; III - quando nele estiver postulando, como defensor público, advogado ou membro do Ministério Público, seu cônjuge ou companheiro, ou qualquer parente, consanguíneo ou afim, em linha reta ou colateral, até o terceiro grau, inclusive;

IV - quando for parte no processo ele próprio, seu cônjuge ou companheiro, ou parente, consanguíneo ou afim, em linha reta ou colateral, até o terceiro grau, inclusive;

V - quando for sócio ou membro de direção ou de administração de pessoa jurídica parte no processo;

\footnotetext{
31 Ibid.
} 
Revista Eletrônica de Direito Processual - REDP.

Rio de Janeiro. Ano 13. Volume 20. Número 1. Janeiro a Abril de 2019

Periódico Quadrimestral da Pós-Graduação Stricto Sensu em Direito Processual da UERJ

Patrono: José Carlos Barbosa Moreira (in mem.). ISSN 1982-7636. pp. 442-476

www.redp.uerj.br

VI - quando for herdeiro presuntivo, donatário ou empregador de

qualquer das partes;

VII - em que figure como parte instituição de ensino com a qual tenha relação de emprego ou decorrente de contrato de prestação de serviços;

VIII - em que figure como parte cliente do escritório de advocacia de seu cônjuge, companheiro ou parente, consanguíneo ou afim, em linha reta ou colateral, até o terceiro grau, inclusive, mesmo que patrocinado por advogado de outro escritório;

IX - quando promover ação contra a parte ou seu advogado.

$\S 1$ o $\mathrm{Na}$ hipótese do inciso III, o impedimento só se verifica quando o defensor público, o advogado ou o membro do Ministério Público já integrava o processo antes do início da atividade judicante do juiz.

$\S 2$ É vedada a criação de fato superveniente a fim de caracterizar impedimento do juiz.

$\S 3^{\circ} \mathrm{O}$ impedimento previsto no inciso III também se verifica no caso de mandato conferido a membro de escritório de advocacia que tenha em seus quadros advogado que individualmente ostente a condição nele prevista, mesmo que não intervenha diretamente no processo.

Art. 145. Há suspeição do juiz:

I - amigo íntimo ou inimigo de qualquer das partes ou de seus advogados;

II - que receber presentes de pessoas que tiverem interesse na causa antes ou depois de iniciado o processo, que aconselhar alguma das partes acerca do objeto da causa ou que subministrar meios para atender às despesas do litígio;

III - quando qualquer das partes for sua credora ou devedora, de seu cônjuge ou companheiro ou de parentes destes, em linha reta até o terceiro grau, inclusive;

IV - interessado no julgamento do processo em favor de qualquer das partes.

$\S 1$ o Poderá o juiz declarar-se suspeito por motivo de foro íntimo, sem necessidade de declarar suas razões.

$\S 2$ - Será ilegítima a alegação de suspeição quando:

I - houver sido provocada por quem a alega; 
Revista Eletrônica de Direito Processual - REDP.

Rio de Janeiro. Ano 13. Volume 20. Número 1. Janeiro a Abril de 2019

Periódico Quadrimestral da Pós-Graduação Stricto Sensu em Direito Processual da UERJ

Patrono: José Carlos Barbosa Moreira (in mem.). ISSN 1982-7636. pp. 442-476

www.redp.uerj.br

II - a parte que a alega houver praticado ato que signifique manifesta aceitação do arguido. ${ }^{32}$

Um cotejo elementar entre os dispositivos legais previstos no atual diploma legal (bem como no de 1973) em oposição ao de 1939, nos mostra claramente que o legislador, - além de alargar as hipóteses em que entende pela existência do vício de capacidade subjetiva -, passou a expressamente distinguir entre os defeitos do impedimento e da suspeição, não obstante ter deixado de disciplinar explicitamente os casos de incompatibilidade (não obstante alguns autores sugerirem a previsão legal desta mácula no art. 136 do $\mathrm{CPC} / 73)^{33}$.

Embora todas as três espécies, - impedimento, suspeição e incompatibilidade -, se caracterizem, em termos amplos, como defeitos graves de imparcialidade, com efeito de poder comprometer seriamente o substrato básico da relação processual, as diferenças que o legislador acabou por estabelecer entre as mesmas, notadamente entre o impedimento e a suspeição, passaram a ser fundamentais para o aprofundamento dos estudos sobre os vícios de capacidade subjetiva do juiz e suas diversas implicações para o processo.

É importante frisar que quando se afirma genericamente que o magistrado é subjetivamente incapaz, na verdade, está se asseverando que o julgador é, de modo geral, suspeito de parcialidade e, não propriamente impedido por vício de isenção.

A par dessa caracterização, a doutrina, - mesmo antes da sistematização legislativa inaugurada com o advento dos CPC/1973 ${ }^{34}$ e CPC/2015 35 -, passou a interpretar o vício do impedimento de forma transcendente à simples suspeita de parcialidade, buscando reservar o termo àquelas situações determinadas, em que a lei entende a parcialidade do julgador como indubitável.

Não é por outra razão que nos casos de impedimento, previstos nos arts. $134 \mathrm{e}$ 136 do CPC/1973 ${ }^{36}$ e nos arts. 144 e 145 do CPC/2015 ${ }^{37}$, o juiz se encontra simplesmente proibido de exercer suas funções no processo, ensejando, no caso de descumprimento

\footnotetext{
${ }^{32}$ BRASIL, op. cit

${ }^{33}$ BRASIL, op. cit.

${ }^{34}$ BRASIL, op. cit.

${ }^{35}$ BRASIL, op. cit.

${ }^{36}$ BRASIL, op. cit.

${ }^{37}$ BRASIL, op. cit.
} 
Revista Eletrônica de Direito Processual - REDP.

Rio de Janeiro. Ano 13. Volume 20. Número 1. Janeiro a Abril de 2019

Periódico Quadrimestral da Pós-Graduação Stricto Sensu em Direito Processual da UERJ

Patrono: José Carlos Barbosa Moreira (in mem.). ISSN 1982-7636. pp. 442-476

www.redp.uerj.br

desta determinação, a própria anulação da sentença através da interposição e ulterior provimento da competente ação autônoma de impugnação (ação rescisória).

Quem está sob suspeição está em situação de dúvida quanto ao seu bom procedimento. Quem está impedido está fora de dúvida, pela enorme probabilidade de ter influência maléfica para a sua função. ${ }^{38}$

A par de todas estas considerações, resta conclusivo que o impedimento se constitui em uma vedação insuperável; um verdadeiro obstáculo intransponível que, de todas as formas, proíbe o juiz de exercer sua função jurisdicional no processo.

As circunstâncias previstas como de impedimento, diferente das de suspeição por imperativo legal, contêm efetiva presunção juris et de jure, ou seja, absoluta (e, portanto insuperável) de parcialidade do julgador e se encontram fundadas em fatos objetivos de fácil constatação. A lei, nestas hipóteses, admite a simples suspeita de parcialidade por inexistir, in casu, qualquer dúvida sobre a situação de absoluta ausência de isenção, na condução do julgamento, por parte do juiz.

Os casos de impedimento (...) contêm verdadeira presunção juris et de jure de parcialidade. São todos eles fundados em fatos objetivos, de fácil comprovação, não dependendo do sentimento real do juiz em elação aos participantes do processo, nem de ter ele interesse efetivo no seu desfecho. ${ }^{39}$

Os impedimentos do juiz, isto é, àquelas hipóteses em que ele, mais do que suspeito de parcialidade, está em situação em que esta se acha fora de dúvida ou se apresenta como fora de dúvida. Nessas hipóteses, o juiz está impedido, quer dizer, proibido de exercer suas funções no processo. ${ }^{40}$

Por outras palavras, o impedimento corresponde à situação do juiz que, por força e lei, o qualifica de parcial; essa situação lhe atribui a presunção

\footnotetext{
${ }^{38}$ MIRANDA apud SANTOS, Moacyr Amaral dos. Primeiras Linhas de Direito Processual, vol. II, $2^{\mathrm{a}}$ ed., Ed. Saraiva, 1985, p. 197.

${ }^{39}$ BARBI, op. cit., p. 549.

${ }^{40}$ SANTOS, op. cit., p. 344.
} 
Revista Eletrônica de Direito Processual - REDP.

Rio de Janeiro. Ano 13. Volume 20. Número 1. Janeiro a Abril de 2019

Periódico Quadrimestral da Pós-Graduação Stricto Sensu em Direito Processual da UERJ

Patrono: José Carlos Barbosa Moreira (in mem.). ISSN 1982-7636. pp. 442-476

www.redp.uerj.br

absoluta de parcialidade. Por isso mesmo, o juiz impedido está proibido de exercer as suas funções no processo, seja este contencioso ou voluntário: "É defeso ao juiz exercer as funções no processo contencioso ou voluntário...". Impedido de exercer suas funções, os atos que praticar são inválidos, ainda que não suscita a exceção de impedimento, sendo a sentença, que proferir, suscetível de ser rescindida por via de ação rescisória. ${ }^{41}$

As hipóteses legais do impedimento estão previstas nos arts. 134 e 136 do CPC $/ 1973^{42}$ e na atual legislação processual civil ${ }^{43}$ nos arts. 144 e $147^{44}$, além de nos arts. 252 e 253 do $\mathrm{CPP}^{45}$.

\section{CONCEITO DE SUSPEIÇÃO}

Diferente do impedimento, onde há presunção absoluta de parcialidade do julgador, a proibir, de forma insuperável, sua participação no processo, nos casos de suspeição, existe apenas a suspeita de parcialidade que obsta, entretanto, o juiz, de exercer suas funções jurisdicionais, apenas quando o mesmo reconhecer tal condição correspondente, ou for julgado suspeito.

Mesmo na doutrina mais abalizada a respeito, no entanto, existem algumas dúvidas quanto à afirmação habitual de que, nas hipóteses contempladas pela lei de regência, na suspeição, de forma diversa dos casos de impedimento, haveria apenas presunção iuris tantum (relativa, portanto) de parcialidade do julgador, em face da própria possibilidade de superação do vício em questão.

Na suspeição, há também presunção absoluta de parcialidade, porque o juiz, se estiver em qualquer das situações previstas na Lei vigente, deverá abster-se de funcionar no processo. E, se não abstiver, a parte poderá

\footnotetext{
${ }^{41}$ BRASIL, op. cit., art. 845, no II, p. 197

${ }^{42}$ BRASIL, op. cit.

${ }^{43}$ BRASIL, op. cit.

${ }^{44}$ BRASIL, op. cit.

${ }^{45}$ BRASIL, op. cit.
} 
Revista Eletrônica de Direito Processual - REDP.

Rio de Janeiro. Ano 13. Volume 20. Número 1. Janeiro a Abril de 2019

Periódico Quadrimestral da Pós-Graduação Stricto Sensu em Direito Processual da UERJ

Patrono: José Carlos Barbosa Moreira (in mem.). ISSN 1982-7636. pp. 442-476

www.redp.uerj.br

promover o afastamento, provando a existência de um daqueles

motivos. ${ }^{46}$

Muito embora ambas as posições devam ser respeitadas dentro do contexto de seus próprios antagonismos, resta indiscutível, data maxima venia, o caráter subjetivo menos gravoso da suspeição em confronto com a condição objetiva mais gravosa do impedimento.

Se por um lado, o impedimento e a suspeição podem ser considerados, de maneira geral, vícios que destroem a necessária presunção de imparcialidade do magistrado, - requisito fundamental de validade da relação processual (vale lembrar que a imparcialidade é, ao lado da investidura e da competência, pressuposto processual subjetivo atinente ao juiz) -, por outro, a lei não deixa de reconhecer suas diversidades atribuindo, de forma diferenciada, pesos e, principalmente, efeitos absolutamente diversos às duas distintas espécies.

O impedimento se caracteriza como fenômeno inibido, por excelência, do poder jurisdicional. Trata-se, a bem da verdade, de vício de tamanha magnitude em sua inerente gravidade que a própria lei processual o promoveu à condição de um dos fundamentos basilares da principal ação autônoma de impugnação no processo civil (ação rescisória - art. 966, II, do CPC/2015) ${ }^{47}$ e no processo penal (revisão criminal - art. 621, I, c/ cart. 626 do CPP) ${ }^{48}$, além de permitir a mais ampla oportunidade de sua argüição (que pode ser processada em qualquer tempo, grau de jurisdição e instância), independentemente do oferecimento de exceção específica (arts. 146 do CPC/2015 e arts. 112 do CPP $)^{49},{ }^{50}$ e plena flexibilidade de conhecimento, inclusive ex officio revelando sua natureza jurídica de objeção.

A suspeição, por seu turno, se expressa como obstáculo à plenitude da correta manifestação do poder jurisdicional. Diferente das hipóteses de impedimento, cujo elenco normativo é numerus clausus (taxativo), os casos previstos de suspeição do magistrado, especialmente no Código de Processo Civil, não se esgotam na disciplina do art. 145, até

\footnotetext{
${ }^{46}$ BARBI, op. cit., p. 59.

${ }^{47}$ BRASIL, op. cit.

${ }^{48}$ BRASIL, op. cit.

${ }^{49}$ BRASIL, op. cit.

${ }^{50}$ BRASIL, op. cit.
} 
Revista Eletrônica de Direito Processual - REDP.

Rio de Janeiro. Ano 13. Volume 20. Número 1. Janeiro a Abril de 2019

Periódico Quadrimestral da Pós-Graduação Stricto Sensu em Direito Processual da UERJ

Patrono: José Carlos Barbosa Moreira (in mem.). ISSN 1982-7636. pp. 442-476

www.redp.uerj.br

porque o dispositivo prevê, em seu parágrafo primeiro, a situação genérica e subjetiva do "motivo de foro íntimo".

Por fim, impende registrar que a suspeição não acarreta as mesmas graves conseqüências previstas para os casos de impedimento. Muito embora a suspeição, - por se caracterizar como vício que afasta a capacidade subjetiva do julgador, e seu correspondente dever de julgar com absoluta isenção -, se constitua na mesma obrigação (registrada no impedimento) de o juiz se abster de decidir a causa, para a qual reputa-se fundada a presunção de sua parcialidade, a lei processual em vigor não prevê nenhum tipo de sanção efetiva para o caso de o magistrado simplesmente ignorar o mandamento legal e deixar de declinar quanto ao dever de se afastar do julgamento.

\section{INOVAÇÕES INTRODUZIDAS DO CPC/2015}

Conforme já expusemos alhures, a imparcialidade do julgador é uma garantia constitucional que decorre dos princípios do devido processo legal ${ }^{51}$ e da igualdade ${ }^{52}$, bem como se constitui pressuposto de validade do processo (ainda que com algumas controvérsias doutrinárias), o que se mantém precípuo no novo codex processual.

O primeiro ponto decorrente da alteração legislativa que podemos destacar, diz respeito ao novo procedimento instituído com o propósito de arguir os (supostos) vícios de impedimento e suspeição nos autos. O novo Código de Processo Civil aboliu as exceções, ou seja, os vícios de impedimento e suspeição, hodiernamente, são alegáveis (de modo mais simplificado) por mera petição, no prazo de 15 (quinze) dias, contados do conhecimento do fato. ${ }^{53}$

No entanto, há que se atentar para o fato de que, tratando-se o impedimento de vício grave, de caráter objetivo e que gera presunção absoluta de parcialidade, sendo, ainda, matéria de ordem pública, não está sujeito à preclusão, podendo ser alegado a qualquer tempo, o que foi mantido na nova ordem processual. Destarte, os atos praticados pelo Juiz impedido são tidos como nulos, cabendo ação rescisória em face da decisão proferida $^{54}$. Conforme leciona Arruda Alvim:

\footnotetext{
${ }^{51}$ BRASIL, op. cit., artigo $5^{\circ}$, LIV.

${ }^{52}$ BRASIL, op. cit., artigo $5^{\circ}$, caput.

${ }^{53}$ BRASIL, op. cit., art. 146.

${ }^{54}$ BRASIL, op. cit., artigo 966, II.
} 
Revista Eletrônica de Direito Processual - REDP.

Rio de Janeiro. Ano 13. Volume 20. Número 1. Janeiro a Abril de 2019

Periódico Quadrimestral da Pós-Graduação Stricto Sensu em Direito Processual da UERJ

Patrono: José Carlos Barbosa Moreira (in mem.). ISSN 1982-7636. pp. 442-476

www.redp.uerj.br

(...) havendo presunção absoluta de parcialidade do julgador, a decisão pode ser desconstituída pela via da ação rescisória. É importante notar que, em se tratando de decisão colegiada, o impedimento de apenas um dos julgadores não autoriza a rescisão do julgado caso este tenha prolatado voto vencido. ${ }^{55}$

Já nos casos de suspeição, caso arguida no prazo legal, o juiz poderá atuar no processo, sendo que a invalidação dos atos processuais depende da prova do prejuízo causado à parte (pas de nullité sans grief), considerando a possibilidade de ratificação $a$ posteriori pelo Juízo imparcial competente.

(...) A suspeição é considerada vício de menor gravidade, o que se depreende do exemplificativo rol do art. 254 (CPP), que atestam a dúvida do legislador acerca da atuação jurisdicional imparcial nessas hipóteses, que representam, muitas vezes, tênues e situacionais ligações do magistrado com os demais sujeitos processuais, sendo mera possibilidade de parcialidade. Diante das inúmeras hipóteses ensejadoras da suspeição, a ausência de um marco temporal preclusivo inviabilizaria a prestação jurisdicional, relativizando perigosamente a coisa julgada. Não é por outra razão que a suspeição, sob pena de preclusão temporal e lógica, deve ser proposta por ocasião da apresentação resposta à acusação, se a hipótese de suspeição era conhecida, ou deveria ser; ou na primeira oportunidade em que o réu se manifestar nos autos, se não era possível a ciência da causa de suspeição ou se é superveniente. $(. . .)^{56}$

$\mathrm{O} \mathrm{CPC} / 2015^{57}$ inovou igualmente ao aumentar as causas de impedimento, acrescentando a este instituto uma hipótese outrora prevista como suspeição (que anteriormente estava prevista no art. 135, III do CPC/73, - quando o Magistrado for

\footnotetext{
${ }^{55}$ ALVIM, Arruda. Novo Contencioso Cível no CPC/2015, São Paulo, RT, 2016.p. 324.

${ }^{56}$ SUPERIOR Tribunal de Justiça STJ - RECURSO EM HABEAS CORPUS: RHC n. 57.488/RS, Ministro Ribeiro Dantas, Quinta Turma, DJe 17/6/2016. Disponível em: <https://stj.jusbrasil.com.br/jurisprudencia/182884123/recurso-em-habeas-corpus-rhc-57488-rs-20150047164-0>. Acesso: 05 fev. 2019.

${ }^{57}$ BRASIL, op. cit.
} 
Revista Eletrônica de Direito Processual - REDP.

Rio de Janeiro. Ano 13. Volume 20. Número 1. Janeiro a Abril de 2019

Periódico Quadrimestral da Pós-Graduação Stricto Sensu em Direito Processual da UERJ

Patrono: José Carlos Barbosa Moreira (in mem.). ISSN 1982-7636. pp. 442-476

www.redp.uerj.br

herdeiro presuntivo, donatário ou empregador de qualquer das partes -, agora aparecendo como exemplo de impedimento no art. 144, VI do CPC/2015). Esta ampliação dos casos de impedimento corrobora a intenção do legislador em afastar, com maior contundência, o julgador reputado parcial.

Outro tópico a ser apontado diz respeito à instância a qual o Magistrado tenha decidido no processo, para fins de caracterização do impedimento. O CPC/73 $3^{58}$ dispunha que era defeso ao juiz exercer as suas funções em processo no qual tenha proferido sentença ou decisão, em primeiro grau de jurisdição (art. 134, inciso III), ao passo que o $\mathrm{CPC} / 2015^{59}$ concedeu uma nova abrangência ao instituto, afirmando haver impedimento do juiz que tenha proferido decisão (lato sensu) no processo, em outro grau de jurisdição $o^{60}$, não estando mais restrito à atuação unicamente no primeiro grau, portanto.

Por outro lado, no que tange ao tipo de decisão proferida, o entendimento do Egrégio Superior Tribunal de Justiça tem se encaminhado pela ausência de impedimento do Magistrado, ante a prática, por parte de seu cônjuge/companheiro, de atos sem conteúdo meritório. Neste sentido, confira-se:

(...) A vedação à atuação concomitante de juízes, consubstanciada nos arts. 136 do CPC/73 e 128 da LOMAN, tem o nítido escopo de evitar que magistrados que atuem perante órgãos colegiados, por força de vínculos afetivos e familiares, acabem se influenciando reciprocamente, prejudicando, desta forma, a autonomia funcional e interpretativa, essencial ao exercício da judicatura. (...). Na hipótese, não houve qualquer pronunciamento sobre o mérito da questão, ou qualquer manifestação que pudesse influenciar no julgamento do mérito da causa, apreciado quando do julgamento da apelação, motivo pelo qual há de se manter a rejeição à exceção de impedimento oposta. ${ }^{61}$

\footnotetext{
${ }^{58}$ BRASIL, op. cit.

${ }^{59}$ BRASIL, op. cit.

${ }^{60}$ BRASIL, op. cit., art. 144, inciso II.

${ }^{61}$ SUPERIOR Tribunal de Justiça STJ - RECURSO ESPECIAL: REsp n. 1673327 SC 2015/0023129-4. Ministra Nancy Andrighi, $3^{\text {a }}$ Turma, DJe 15/09/2017. Disponível em: <https://stj.jusbrasil.com.br/jurisprudencia/499418488/recurso-especial-resp-1673327-sc-2015-0023129-4>. Acesso: 05 fev. 2019.
} 
Revista Eletrônica de Direito Processual - REDP.

Rio de Janeiro. Ano 13. Volume 20. Número 1. Janeiro a Abril de 2019

Periódico Quadrimestral da Pós-Graduação Stricto Sensu em Direito Processual da UERJ

Patrono: José Carlos Barbosa Moreira (in mem.). ISSN 1982-7636. pp. 442-476

www.redp.uerj.br

É notória também a mens legis no sentido da extensão do grau de parentesco, para efeito de presunção do impedimento (presunção absoluta), não só com relação à inclusão do companheiro (união estável), na esteira das mudanças já ocorridas com o Novo Código $\mathrm{Civil}^{62}$, bem como das carreiras exercidas no feito pelo cônjuge/companheiro ou pelos parentes do Juiz.

Se antes o $\mathrm{CPC} / 73^{63}$ entendia como impedido o Magistrado cujo cônjuge/companheiro ou parentes tenham postulado como advogados da parte, e limitava o parentesco colateral ao segundo grau $^{64}$; o $\mathrm{CPC} / 2015^{65}$ estendeu tal presunção aos parentes até o terceiro grau inclusive (v.g., seu cunhado, - colateral no segundo grau -, ou a esposa de seu sobrinho, - colateral no terceiro grau), sendo certo que se excluem os primos (que são parentes no quarto grau), bem como acrescentou a intervenção dos ditos parentes ou do cônjuge/companheiro do Juiz no processo como Defensores Públicos ou membros do Ministério Público. ${ }^{6}$ Em qualquer caso, o impedimento só se verificaria caso o advogado já integrasse o processo antes do início da atividade judicante do juiz. ${ }^{67}$

O impedimento estende-se ao escritório de advocacia, mesmo que o cônjuge/companheiro ou parente não tenha intervindo diretamente no processo ${ }^{68}$, e ainda que o cliente seja patrocinado por advogado de outro escritório. ${ }^{69}$ Ao fazer referência a escritório de advocacia e não a sociedade de advogados, o parágrafo terceiro não restringe o impedimento à condição de sócio do advogado parente do juiz. Basta que ele interaja, na condição de advogado - e não de estagiário, por exemplo - em escritório de advocacia que atue na causa.

Nota-se claramente que esta proibição, aliada àquela descrita no inciso III do mesmo dispositivo, volta-se ao combate franco e claro ao tráfico de influência no âmbito processual, uma vez que o impedimento se fará presente mesmo que a pessoa que carrega o motivo do impedimento não atue diretamente no feito. ${ }^{70}$

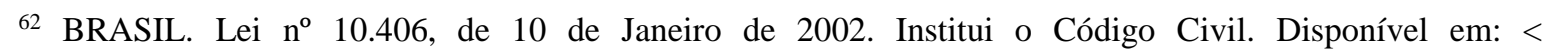
http://www.planalto.gov.br/ccivil_03/LEIS/2002/L10406.htm>. Acesso: 04 fev. 2019.

${ }^{63}$ BRASIL, op. cit.

${ }^{64}$ BRASIL, op. cit., art. 134, inciso IV.

${ }^{65}$ BRASIL, op. cit.

${ }^{66}$ BRASIL, op. cit., art. 144, inciso III.

${ }^{67}$ BRASIL, op. cit., art. $144, \S 1^{\circ}$.

${ }^{68}$ BRASIL, op. cit., art. $144, \S 3^{\circ}$.

${ }^{69}$ BRASIL, op. cit., inciso VIII.

${ }^{70}$ BRASIL, op. cit., art. 144, inciso VIII, in fine, e $\$ 3^{\circ}$. 
Revista Eletrônica de Direito Processual - REDP.

Rio de Janeiro. Ano 13. Volume 20. Número 1. Janeiro a Abril de 2019

Periódico Quadrimestral da Pós-Graduação Stricto Sensu em Direito Processual da UERJ

Patrono: José Carlos Barbosa Moreira (in mem.). ISSN 1982-7636. pp. 442-476

www.redp.uerj.br

O juiz, porém, não se torna impedido se, já atuando no processo,

posteriormente passe a funcionar seu cônjuge/companheiro ou parente como Defensor Público, Advogado ou membro do Ministério Público ${ }^{71}$, porque isso constituiria modo de, a qualquer tempo, provocar o impedimento do juiz. É o Defensor Público, advogado, membro do Ministério Público, cônjuge, companheiro ou parente, que fica impedido de atuar no feito, devendo ser substituído, sob pena de extinção do processo ou de revelia, conforme o caso.

Cabe salientar que, na linha reta, a afinidade não se extingue com a dissolução do casamento ou da união estável ${ }^{72}$, razão pela qual se mantém a presunção de parcialidade.

O juiz, outrossim, não pode atuar em processo em que empresa da qual atue como sócio seja parte. ${ }^{73}$ Pode, porém, atuar em processo com empresa de que seja acionista, desde que não integre sua direção ou administração.

De toda forma, o Estatuto da Magistratura ${ }^{74}$ veda ao magistrado exercer o comércio ou participar de sociedade comercial, inclusive de economia mista, exceto como acionista ou quotista, bem como exercer cargo de direção ou técnico de sociedade civil, associação ou fundação, de qualquer natureza ou finalidade, salvo de associação de classe e sem remuneração.

Importante esclarecer que o membro de uma associação, com finalidade social, cultural, desportiva etc, não se caracteriza como sócio. Poderia haver suspeição, mas não impedimento do juiz, in casu.

O inciso VI do art. 144 do CPC/2015 75 , como dissemos supra, prevê uma situação anteriormente definida como suspeição pelo $\mathrm{CPC} / 1973^{76}$, qual seja, quando o Magistrado for herdeiro presuntivo, donatário ou empregador de qualquer das partes. $\mathrm{O}$ impedimento estende-se à diarista, ainda que não se configure emprego, nos termos da legislação trabalhista. O Magistrado também é considerado impedido de atuar em processo

\footnotetext{
${ }^{71}$ BRASIL, op. cit., parágrafo $2^{\circ}$.

72 BRASIL, op. cit., art. $1.595, \S 2^{\circ}$.

${ }^{73}$ BRASIL, op. cit., art. 144, inciso V.

${ }^{74}$ BRASIL. Lei Complementar n ${ }^{\circ}$ 35, de 14 de Março de 1979. Dispõe sobre a Lei Orgânica da Magistratura Nacional. Disponível em: <http://www.planalto.gov.br/ccivil_03/Leis/LCP/Lcp35.htm>. Acesso: 04 fev. 2019.

${ }^{75}$ BRASIL, op. cit., inciso VI do art. 144.

${ }^{76}$ BRASIL, op. cit.
} 
Revista Eletrônica de Direito Processual - REDP.

Rio de Janeiro. Ano 13. Volume 20. Número 1. Janeiro a Abril de 2019

Periódico Quadrimestral da Pós-Graduação Stricto Sensu em Direito Processual da UERJ

Patrono: José Carlos Barbosa Moreira (in mem.). ISSN 1982-7636. pp. 442-476

www.redp.uerj.br

no qual figure como parte instituição de ensino com a qual tenha relação de emprego ou decorrente de contrato de prestação de serviços ${ }^{77}$.

É importante frisar, outrossim, que as hipóteses de suspeição foram reorganizadas pela nova sistemática (considerando-se, inclusive, que se encontram todas nos incisos do art. 145 $)^{78}$. Em que pese as alterações meramente redacionais nos incisos II, III e IV ${ }^{79}$, em relação ao Código anterior, houve significativa renovação no tocante à primeira hipótese de suspeição trazida pelo CPC/2015, verbis:

Art. 145. Há suspeição do juiz:

I - amigo íntimo ou inimigo de qualquer das partes ou de seus advogados; ${ }^{80}$

Anteriormente, a referência era feita apenas às partes, ao passo que na novel legislação, foi acrescentado o causídico, outrossim, como parâmetro para a configuração desta causa de suspeição. Ademais, retirou-se do texto a expressão "inimigo capital”.

Como o receio que fundamenta tal hipótese de suspeição é que os laços pessoais entre o juiz e as partes ou seus advogados comprometam a isenção no julgamento, deve ser conferida interpretação extensiva à regra para também incluir nos casos de suspeição as figuras do defensor público, do procurador (municipal, estadual, da Fazenda Nacional), do advogado da União e do membro do Ministério Público. Amizade íntima é conceito que remete a um vínculo forte, que vai além da mera convivência profissional, estando evidenciado, em tese, pelo noivado ou compadrio, assim como pela visitação frequente de um à residência de outro. O texto do CPC/2015, em comparação ao CPC/1973, não exige mais a inimizade 'capital', ou seja, de se desejar a morte do inimigo. Basta, para que se configure a suspeição, que se evidencie uma emoção

\footnotetext{
${ }^{77}$ BRASIL, op. cit., inciso VII.

${ }^{78}$ BRASIL, op. cit., art. 145.

${ }^{79}$ BRASIL, op. cit.

${ }^{80}$ BRASIL, op. cit.
} 
Revista Eletrônica de Direito Processual - REDP.

Rio de Janeiro. Ano 13. Volume 20. Número 1. Janeiro a Abril de 2019

Periódico Quadrimestral da Pós-Graduação Stricto Sensu em Direito Processual da UERJ

Patrono: José Carlos Barbosa Moreira (in mem.). ISSN 1982-7636. pp. 442-476

www.redp.uerj.br

de caráter negativo, advinda de questões pessoais, que o juiz apresente em relação à parte ou ao advogado. ${ }^{81}$

Ademais, insta salientar que remanesce o entendimento no sentido de que para caracterizar a suspeição prevista na legislação processual vigente, a inimizade entre as partes deve ser pública, recíproca e estar fundada em atritos ou agressões mútuas, não podendo se relacionar com meras rusgas que podem ocorrer no ambiente profissional. ${ }^{82}$

Por fim, diante do art. 148, importa ressaltar que motivos de impedimento e suspeição se aplicam também aos membros do Ministério Público, aos auxiliares da Justiça (elencados no rol exemplificativo do art. 149 do CPC/2015) ${ }^{83}$ e demais sujeitos imparciais do processo, com exceção das testemunhas $\left(\S 4^{\circ}\right)$, objeto de regulamentação específica pelos arts. 447 , caput e $457, \S \S 1^{\circ}$ e $2^{o} .{ }^{84}$

Em qualquer caso, é importante realçar o disposto no Enunciado $\mathrm{n}^{\mathrm{o}} 88 \mathrm{da}$ Súmula do TJSP: “Reiteradas decisões contrárias aos interesses do excipiente, no estrito exercício da atividade jurisdicional, não tornam o juiz excepto suspeito para o julgamento da causa”.

\subsection{Das Inovações Procedidas Quanto à Suspeição por Motivo de Foro Íntimo}

O Novo Código de Processo Civil de $2015^{85}$ consignou (expressamente) a desnecessidade de o Juiz declinar as respectivas razões de sua suspeição por motivo de foro íntimo, conforme previsão contida no art. 145, parágrafo $1^{\circ}$ :

Art. 145. Há suspeição do juiz:

(...).

\footnotetext{
${ }^{81}$ ROQUE, André Vasconcelos. Breves Comentários ao Novo Código de Processo Civil. São Paulo: RT, 2016 , p. 505.

${ }^{82}$ SUPERIOR Tribunal de Justiça STJ - HABEAS CORPUS: HC 204956 SP 2011/0092738-5 - Inteiro Teor. Ministro Jorge Mussi, $5^{\text {a }}$ Turma, DJU: 03/10/2012. Disponível em: <https://stj.jusbrasil.com.br/jurisprudencia/22582748/habeas-corpus-hc-204956-sp-2011-0092738-5stj/inteiro-teor-22582749>. Acesso: 05 fev. 2019.

${ }^{83}$ BRASIL, op. cit.

${ }^{84}$ BRASIL, op. cit., arts. 447, caput e $457, \S \S 1^{\circ}$ e $2^{\circ}$.

${ }^{85}$ BRASIL, op. cit.
} 
Revista Eletrônica de Direito Processual - REDP.

Rio de Janeiro. Ano 13. Volume 20. Número 1. Janeiro a Abril de 2019

Periódico Quadrimestral da Pós-Graduação Stricto Sensu em Direito Processual da UERJ

Patrono: José Carlos Barbosa Moreira (in mem.). ISSN 1982-7636. pp. 442-476

www.redp.uerj.br

$\S 1^{\circ}$. Poderá o juiz declarar-se suspeito por motivo de foro íntimo, sem necessidade de declarar suas razões. ${ }^{86}$

A suspeição por motivo de foro íntimo é aquela alegada pelo próprio julgador, dotada, portanto, de alto grau de subjetividade em relação às hipóteses que podem ser suscitadas pelas partes, razão pela qual não se exige a declaração expressa dos motivos que levaram à quebra da imparcialidade, bastando a mera afirmação da suspeição para que o julgador não mais participe dos demais atos do processo.

Tal dispositivo legal, como se vê, reflete a jurisprudência mansa, pacífica e tranquila a respeito do tema, corroborando o lamentável fato de que a jurisprudência, mesmo quando oriunda de tribunais superiores e da própria Suprema Corte, revela-se como uma fonte do Direito brasileiro constantemente negligenciada, quando não simplesmente desprezada, quer pelo fato de seu simples desconhecimento, quer pelo fato de uma persistente desobediência judiciária.

Uma vez que não são conhecidas as razões da suspeição, porque de domínio exclusivo do julgador, entende-se que a declaração de suspeição por motivo de foro íntimo é irretratável, eis que as partes não podem permanecer inseguras quanto à eventual revogação desta decisão. No entanto, tratando-se de questão complexa e subjetiva, caberá avaliar, no caso concreto, as circunstâncias quanto à eventual retratação.

Ainda por conta desta subjetividade inerente à declaração de suspeição por foro íntimo, não cabe à parte questionar, ou mesmo arguir esta modalidade de suspeição, considerando que apenas o próprio juiz conhece seus motivos. A suspeição é do Magistrado, e não da parte. Por conta disto, não há que falar em abertura de contraditório, afinal, é a neutralidade no julgamento que se está a proteger, antes mesmo do próprio direito individual do magistrado.

Imaginemos a hipótese que um juiz católico extremamente zeloso que tenha de julgar contra os interesses da própria igreja católica. Estaria ele livre no seu convencimento? Acreditamos que não. Outra situação: uma juíza do trabalho que antes de ser juíza viu seu pai, sitiante pequeno, perder todos os bens por demandas trabalhistas de trabalhadores rurais, demandas duvidosas, mas que colocaram a família em situação

\footnotetext{
${ }^{86}$ BRASIL, op. cit., art. 145 , parágrafo $1^{\circ}$.
} 
Revista Eletrônica de Direito Processual - REDP.

Rio de Janeiro. Ano 13. Volume 20. Número 1. Janeiro a Abril de 2019

Periódico Quadrimestral da Pós-Graduação Stricto Sensu em Direito Processual da UERJ

Patrono: José Carlos Barbosa Moreira (in mem.). ISSN 1982-7636. pp. 442-476

www.redp.uerj.br

de miséria, miséria esta que a juíza viveu no campo das angustias e injustiças. Estaria

ela livre para julgar, agora como juíza do trabalho, demandas de pequenos proprietários rurais? Será que seu convencimento estaria realmente livre das lembranças do seu passado? E o caso do juiz descendente de judeu que agora tem de julgar adepto ao nazismo. Estaria ele com seu convencimento realmente livre? Juiz que perdeu pai de câncer provocado por cigarro em angustioso sofrimento. O juiz é não fumante e viveu todo o sofrimento familiar por causa do fumo. Diante de causa de reparação de danos de fumante contra a indústria do tabaco. Seu convencimento estará livre para julgá-las? ${ }^{87}$

Também não se pode olvidar que uma das razões decisivas que ensejaram a (redundante) inserção da expressão "sem necessidade de declarar suas razões" no novo texto legal repousa justamente na reconhecida carência de conhecimentos técnicoprocessuais por parte dos atuais e mais jovens operadores do Direito (juízes, membros do Ministério Público e advogados), problemática que é fruto de um ensino jurídico de péssima qualidade e que negligencia a importância da disciplina hermenêutica, reduzindoa a condenáveis debates político-ideológicos.

Nada obstante a clareza da regra consubstanciada no CPC $/ 2015^{88}$, o Conselho Nacional de Justiça - CNJ, por meio do Ofício Circular nº 22, de 3 de junho de 2016, determinou a observância da Resolução $n^{\circ}$ 82/2009, o que ensejou o ajuizamento de Mandado de Segurança Coletivo ( $\mathrm{n}^{\circ}$ 34.316) junto à Corte Suprema, tendo o Ministro Teori Zavascki, em sede de pedido de liminar, decidido em 22 de agosto de 2016, da seguinte forma:

Trata-se de mandado de segurança coletivo, com pedido de liminar, impetrado pela Associação dos Magistrados Brasileiros (AMB), pela Associação Nacional dos Magistrados da Justiça do Trabalho (ANAMATRA) e pela Associação dos Juízes Federais do Brasil (AJUFE) contra ato da Corregedora Nacional de Justiça 'consubstanciado no Ofício Circular n. 22, de 3 de junho de 2016, que determinou a observância da Resolução $n^{o} 82$ do CNJ' (fl. 1). Inicialmente, as impetrantes

\footnotetext{
${ }^{87}$ FERNANDEZ, Alex Aparecido Ramos. Acesso à justiça através de um juízo imparcial: exceção de suspeição e impedimento, Dissertação (Mestrado em Direito), Faculdade Autônoma de Direito, FADISP, São Paulo, 2009.

${ }^{88}$ BRASIL, op. cit.
} 
Revista Eletrônica de Direito Processual - REDP.

Rio de Janeiro. Ano 13. Volume 20. Número 1. Janeiro a Abril de 2019

Periódico Quadrimestral da Pós-Graduação Stricto Sensu em Direito Processual da UERJ

Patrono: José Carlos Barbosa Moreira (in mem.). ISSN 1982-7636. pp. 442-476

www.redp.uerj.br

apresentam os seguintes fatos: (a) por meio da Resolução 82, havia o Conselho

Nacional de Justiça criado norma exigindo dos magistrados que informassem às corregedorias a que estivessem vinculados as razões do 'foro intimo' invocado nos processos em que afirmassem suspeição; (b) essa resolução foi atacada por meio de ação direta de inconstitucionalidade (ADI 4.260), tendo, a Relatora, Min. Rosa Weber, determinado a observância do rito do art. 12 da Lei 9.868/1999, o que inviabilizou a apreciação do pedido de medida cautelar; (c) assim, apresentaram Pedido de Providências perante o CNJ para suspender a eficácia dessa resolução, o qual não foi apreciado; (d) em seguida, impetraram mandado de segurança nesta Corte (MS 28.215), tendo o então Relator, Min. Ayres Britto, deferido o pedido de liminar; (e) em 2015, o mandado de segurança teve seu pedido negado com base na Súmula 266/STF, o que resultou na revogação da liminar; (f) intimados pela autoridade impetrada para que se manifestassem nos autos do referido Pedido de Providências, postularam a suspensão da eficácia da resolução ante a superveniência do novo código de processo civil (CPC/2015), o qual dispensa o magistrado de declarar as razões da declaração de suspeição por motivo de foro íntimo; (g) distribuídos os autos ao Conselheiro Arnaldo Hossepian Júnior, o pedido foi indeferido pelo fundamento de que a matéria fora judicializada na ADI 4.260; (h) em 3/6/2016, a autoridade impetrada expediu o Ofício Circular 22 determinando a observação da Resolução 82, sendo esse o ato atacado no presente mandado de segurança. Quanto ao mérito, sustentam as impetrantes que: (I) o CPC/15 (Lei n. 13.105/2015), indo além do CPC/73, deixa claro que, ao declarar a suspeição por motivo íntimo, o magistrado assim o fará sem necessidade de declarar suas razões; (II) nos termos do $\S 1^{\circ}$ do art. $2^{\circ}$ da Lei de Introdução às Normas do Direito Brasileiro, 'a lei posterior revoga a anterior quando expressamente o declare, quando seja com ela incompatível ou quando regule inteiramente a matéria de que tratava a lei anterior'; (III) 'o $\S 1^{o} d o$ art. 145 não apenas regulou inteiramente a matéria de que trata a Resolução $n^{o}$ 82, como também a nova redação da lei se mostra incompatível com o da Resolução $n$. 82 '; (IV) também nos processos de natureza penal a norma aplicável sobre a suspeição por motivo íntimo era e continua sendo a do CPC (fl. 9). No mais, informam que (i) 'há procedimento em curso perante o CNJ visando a obter o pronunciamento do seu Plenário sobre a ocorrência ou não da revogação da Resolução n. 82'; e (ii) o Grupo de Trabalho formado no CNJ para discutir o novo CPC sugere a revogação dessa resolução (fl. 7). Requerem a concessão de liminar para a suspensão dos efeitos do Ofício Circular 22/2016 até o final julgamento do mandado de segurança, invocando, 
Revista Eletrônica de Direito Processual - REDP.

Rio de Janeiro. Ano 13. Volume 20. Número 1. Janeiro a Abril de 2019

Periódico Quadrimestral da Pós-Graduação Stricto Sensu em Direito Processual da UERJ

Patrono: José Carlos Barbosa Moreira (in mem.). ISSN 1982-7636. pp. 442-476

www.redp.uerj.br

a título de periculum in mora, o conteúdo do ato impetrado, que reitera a exigência dos termos da Resolução 82 do CNJ. Pedem, ao final, seja concedida a ordem para 'declarar inexigivel aos magistrados as normas contidas na Resolução n. 82 do CNJ, uma vez que foi revogada pelo $\S 1^{\circ}$ do art. 145 do Código de Processo Civil de 2015' (fl. 12).

Atendendo a despacho da Presidência proferido em 25/7/2016, a autoridade impetrada prestou informações (doc. 31).

O deferimento de medidas liminares pressupõe presentes a relevância jurídica da pretensão, bem como a indispensabilidade da providência antecipada, como forma de garantir a efetividade de futuro e provável juízo de procedência. No caso, está configurada a relevância do direito afirmado pelas impetrantes, tendo em vista que o ato normativo que a autoridade coatora exige seja cumprido tornou-se, à primeira vista, incompatível com a superveniência do novo código de processo civil (CPC/2015), segundo o qual 'Poderá o juiz declarar-se suspeito por motivo de foro intimo, sem necessidade de declarar suas razões' (art. 145, $\S 1^{\circ}$ ). Nessas circunstâncias, deve ser suspensa a eficácia do ato impetrado (Ofício Circular 22/2016, da Corregedora Nacional de Justiça), ressaltando-se, ademais, que não está o CNJ impedido de examinar, em procedimento próprio, o tema da revogação da Resolução 82 pelo CPC/2015.

Ante o exposto, defiro a liminar para suspender os efeitos do Ofício Circular 22/2016 da Corregedora Nacional de Justiça. Solicitem-se informações, procedendo-se aos demais atos previstos no art. $7^{\circ}$, I e II da Lei $12.016 / 09 .{ }^{89}$

Cumpre registrar, por derradeiro, que o CNJ, na $18^{\mathrm{a}}$ Sessão do Plenário Virtual (25/08/2016 à 30/08/2016), finalmente revogou a malsinada Resolução, tendo o Relator, o Conselheiro Gustavo Alkmim, expressamente reconhecido que "o legislador, quando modificou o normativo processual sobre o tema, buscou preservar a intimidade do Magistrado, garantindo a sua independência e imparcialidade, sem presumir, de plano, o uso abusivo do seu direito de se afastar do processo por motivo de foro íntimo."

\section{CONCLUSÕES}

${ }^{89}$ SUPREMO Tribunal Federal STF - MEDIDA CAUTELAR EM MANDADO DE SEGURANÇA: MC MS 4002798-15.2016.1.00.0000 DF - DISTRITO FEDERAL 4002798-15.2016.1.00.0000. Disponível em: <https://stf.jusbrasil.com.br/jurisprudencia/378052447/medida-cautelar-em-mandado-de-seguranca-mc-ms34316-df-distrito-federal-4002798-1520161000000>. Acesso: 05 fev. 2019. 
Revista Eletrônica de Direito Processual - REDP.

Rio de Janeiro. Ano 13. Volume 20. Número 1. Janeiro a Abril de 2019

Periódico Quadrimestral da Pós-Graduação Stricto Sensu em Direito Processual da UERJ

Patrono: José Carlos Barbosa Moreira (in mem.). ISSN 1982-7636. pp. 442-476

www.redp.uerj.br

Conforme afirmado, o Magistrado não deve, em nenhuma hipótese, julgar e nem realizar qualquer processamento para o qual não entenda estar na absoluta plenitude das condições de isenção objetivas (impedimento) e subjetivas (suspeição), na exata medida em que cabe ao próprio Juiz velar pela completa imparcialidade e independência em seus julgamentos, como condição básica e fundamental para assegurar a inequívoca presença dos preceitos e garantias, relativos ao processo, consagrados na Constituição Federal.

O novo Código de Processo Civil aboliu as exceções (e, igualmente, as chamadas objeções), como modalidade formal de arguição quanto à ausência de isenção do magistrado; ou seja, os vícios de impedimento e suspeição, hodiernamente, são alegáveis (de modo mais simplificado) por mera petição, no prazo de 15 (quinze) dias. Tratando-se o impedimento de vício grave, de caráter objetivo e que gera presunção absoluta de parcialidade, sendo, ainda, matéria de ordem pública, não está sujeito à preclusão, podendo ser alegado a qualquer tempo.

Já nos casos de suspeição, caso arguida no prazo legal, o juiz poderá atuar no processo, sendo que a invalidação dos atos processuais depende da prova do prejuízo causado à parte (pas de nullité sans grief), considerando a possibilidade de ratificação $a$ posteriori pelo Juízo imparcial competente.

Neste diapasão, resta importante registrar, - ajustando qualquer dúvida residual -, que a declaração de suspeição do Magistrado, por razões de ordem íntima, em particular, se caracteriza, à luz da doutrina amplamente majoritária (se não unânime) e da jurisprudência pátria consolidada, em efetivo direito subjetivo próprio, outorgado ao Juiz, para que este possa, em sua completa inteireza, velar pela absoluta imparcialidade e independência em seus julgamentos, como condição básica e fundamental à garantia constitucional do devido processo legal.

O Novo Código de Processo Civil, ao consignar (expressamente) no seu texto a desnecessidade de o Magistrado justificar ou explicitar as razões íntimas que o levaram a se declarar por suspeito, bastando apenas a afirmativa de suspeição, demonstrou, de forma inequívoca, tratar-se de uma faculdade sujeita a seu exclusivo arbítrio, condicionada apenas e tão somente à irrestrita defesa pela permanente presença, na sua atividade jurisdicional, dos elementos mínimos imprescindíveis à garantia do devido processo legal. 
Rio de Janeiro. Ano 13. Volume 20. Número 1. Janeiro a Abril de 2019

Periódico Quadrimestral da Pós-Graduação Stricto Sensu em Direito Processual da UERJ

Patrono: José Carlos Barbosa Moreira (in mem.). ISSN 1982-7636. pp. 442-476 www.redp.uerj.br

\section{REFERÊNCIAS BIBLIOGRÁFICAS:}

ALVIM, Arruda. Novo Contencioso Cível no CPC/2015, São Paulo, RT, 2016.

ASSIS, Araken de. Manual de Processo de Execução, Sérgio Fabris Ed., RS, 1987.

BARBI, Celso Agrícola. Comentários ao Código de Processo Civil, vol. I, $5^{\mathrm{a}}$ ed., Ed. Forense, 1983.

BARBOSA, Rui. Obras Completas de Rui Barbosa. Publicado pelo Ministério de Educação e Saúde, 1942.

BRASIL. Consolidação das leis do trabalho - CLT e normas correlatas. - Brasília:

Senado Federal, Coordenação de Edições Técnicas, 2017. 189 p. Disponível em: $<$ http://www2.senado.leg.br/bdsf/bitstream/handle/id/535468/clt_e_normas_correlata s_1ed.pdf>. Acesso: 04 fev. 2019.

BRASIL. Lei no 13.105, de 16 de Março de 2015. Código de Processo Civil. Disponível em: $\quad$ http://www.planalto.gov.br/ccivil_03/_Ato20152018/2015/Lei/L13105.htm\#art1046>. Acesso: 04 fev. 2019.

BRASIL. Lei no 10.406, de 10 de Janeiro de 2002. Institui o Código Civil. Disponível em: $<$ http://www.planalto.gov.br/ccivil_03/LEIS/2002/L10406.htm $>$. Acesso: 04 fev. 2019.

BRASIL. Constituição (1988). Constituição da República Federativa do Brasil. Brasília, DF: Senado Federal: Centro Gráfico, 1988. 292 p.

BRASIL. Lei Complementar nº 35, de 14 de Março de 1979. Dispõe sobre a Lei Orgânica da Magistratura Nacional. Disponível em: <http://www.planalto.gov.br/ccivil_03/Leis/LCP/Lcp35.htm>. Acesso: 04 fev. 2019.

BRASIL. Lei $n^{\circ}$ 5.869, de 11 de Janeiro de 1973. Institui o Código de Processo Civil. Disponível em: <http://www.planalto.gov.br/ccivil_03/LEIS/L5869impressao.htm>. Acesso: 04 fev. 2019.

BRASIL. Decreto-Lei no 3.689, de 3 de Outubro de 1941. Código de Processo Penal. Brasília: Senado Federal, Coordenação de Edições Técnicas, 2017. 187 p. Disponível em:

< http://www2.senado.leg.br/bdsf/bitstream/handle/id/529749/codigo_de_processo_p enal_1ed.pdf>. Acesso: 04 fev. 2019. 
Revista Eletrônica de Direito Processual - REDP.

Rio de Janeiro. Ano 13. Volume 20. Número 1. Janeiro a Abril de 2019

Periódico Quadrimestral da Pós-Graduação Stricto Sensu em Direito Processual da UERJ

Patrono: José Carlos Barbosa Moreira (in mem.). ISSN 1982-7636. pp. 442-476

www.redp.uerj.br

BRASIL. Decreto-Lei n ${ }^{\circ}$ 1.608, de 18 de Setembro de 1939. Código de Processo Civil.

Disponível em: <http://www.planalto.gov.br/ccivil_03/decreto-lei/19371946/Del1608.htm>. Acesso: 04 fev. 2019.

CHIOVENDA, Giusepe. Instituições de Direito Processual Civil, vol. II, Ed. Bookseller. Campinas, 1998.

CINTRA, Antonio Cunha de A.; GRINOVER, Ada Pellegrini; DINAMARCO, Cândido R.

Teoria Geral do Processo, 9ª ed., Malheiros Ed., SP, 1993.

DECLARAÇÃO Universal Dos Direitos Humanos. Assembleia Geral das Nações

Unidas em Paris. 10 dez. 1948. Disponível em:

<https://www.ohchr.org/EN/UDHR/Pages/Language.aspx?LangID=por>.

Acesso: 05 fev. 2019.

DELGADO, José Luiz. A Democracia e o Judiciário, Diário de Pernambuco, 18/09/91.

FALCÃO, Joaquim. Congresso e Supremo podem fazer Gol Contra, O Globo, 16/12/2016.

FERNANDEZ, Alex Aparecido Ramos. Acesso à justiça através de um juízo imparcial:

exceção de suspeição e impedimento, Dissertação (Mestrado em Direito), Faculdade Autônoma de Direito, FADISP, São Paulo, 2009.

FERREIRA, Aurélio Buarque de Holanda. Novo Dicionário da Língua Portuguesa, $2^{\mathrm{a}}$ ed., Ed. Nova Fronteira, 1986.

GRINOVER, Ada Pellegrini. Teoria Geral do Processo, 9ª ed., Malheiros, Ed., SP, 1993.

MACHADO, Hugo de Brito. Ser e Parecer, Rev. AJUFE, dez./91.

MEIRA, Sílvio. Clamor pela Justiça, Jornal do Comércio, 4/9/92.

ROQUE, André Vasconcelos. Breves Comentários ao Novo Código de Processo Civil. São Paulo: RT, 2016.

SANTOS, Moacyr Amaral dos. Primeiras Linhas de Direito Processual, vol. II, $2^{\mathrm{a}}$ ed., Ed. Saraiva, 1985.

SILVA, Ovídio B. da. Estudos Sobre o Processo Civil Brasileiro, Saraiva, SP, 1947.

SUPERIOR Tribunal de Justiça STJ - RECURSO ESPECIAL: REsp n. 1673327 SC 2015/0023129-4. Ministra Nancy Andrighi, 3ª Turma, DJe 15/09/2017. Disponível em: $\quad$ https://stj.jusbrasil.com.br/jurisprudencia/499418488/recurso-especial-resp1673327-sc-2015-0023129-4>. Acesso: 05 fev. 2019.

SUPERIOR Tribunal de Justiça STJ - RECURSO EM HABEAS CORPUS: RHC n. 57.488/RS. Ministro Ribeiro Dantas, $5^{\text {a }}$ Turma, DJe 17/6/2016. Disponível em: 
Revista Eletrônica de Direito Processual - REDP.

Rio de Janeiro. Ano 13. Volume 20. Número 1. Janeiro a Abril de 2019

Periódico Quadrimestral da Pós-Graduação Stricto Sensu em Direito Processual da UERJ

Patrono: José Carlos Barbosa Moreira (in mem.). ISSN 1982-7636. pp. 442-476 www.redp.uerj.br

<https://stj.jusbrasil.com.br/jurisprudencia/182884123/recurso-em-habeas-corpusrhc-57488-rs-2015-0047164-0). Acesso: 05 fev. 2019.

SUPREMO Tribunal Federal STF - MEDIDA CAUTELAR EM MANDADO DE SEGURANÇA: MC MS 4002798-15.2016.1.00.0000 DF - DISTRITO FEDERAL. 4002798-15.2016.1.00.0000. Ministro Teori Zavascki, 22/08/2016. Disponível em: <https://stf.jusbrasil.com.br/jurisprudencia/378052447/medida-cautelar-emmandado-de-seguranca-mc-ms-34316-df-distrito-federal-4002798-1520161000000>. Acesso: 05 fev. 2019.

SUPERIOR Tribunal de Justiça STJ - HABEAS CORPUS: HC 204956 SP 2011/0092738-

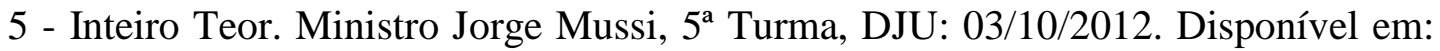
<https://stj.jusbrasil.com.br/jurisprudencia/22582748/habeas-corpus-hc-204956-sp2011-0092738-5-stj/inteiro-teor-22582749>. Acesso: 05 fev. 2019.

TOURINHO FILHO, Fernando da Costa. Processo Penal, vol. II, ed. Saraiva, 12a edição, 2009. 